\title{
Personal Entrepreneurial Skills of Public School Teachers
}

\author{
Geena Baltazar Hipolito \\ Department of Agricultural Business and Economics and Entrepreneurship, Pampanga State Agricultural University, Magalang, \\ Philippines \\ Email: kimnyte@gmail.com
}

How to cite this paper: Hipolito, G.B. (2021) Personal Entrepreneurial Skills of Public School Teachers. Open Access Library Journal, 8: e7135.

https://doi.org/10.4236/oalib.1107135

Received: January 5, 2021

Accepted: March 30, 2021

Published: April 2, 2021

Copyright $\odot 2021$ by author(s) and Open Access Library Inc.

This work is licensed under the Creative Commons Attribution International License (CC BY 4.0).

http://creativecommons.org/licenses/by/4.0/ (c) (i) Open Access

\begin{abstract}
In the Philippines, teachers tend to find other sources of income due to some financial circumstances. With this, some teachers were entrepreneurs (termed as teacherpreneur) during break time and after office hours. This paper determined the profile of the teacher-entrepreneurs and identified the Personal Entrepreneurial Capabilities (PEC) of the aspiring Teacher-Entrepreneurs. Further, this paper assessed the Personal Entrepreneurial Capabilities of the teacher-entrepreneurs as startup for business and evaluated the Personal Entrepreneurial Capabilities of the Respondents before and after the training. A total of 89 teacher entrepreneurs ( 31 females and 58 males) were surveyed using a questionnaire with likert-scale responses. The researcher pointed out the following significant conclusions: first, majority of the respondents were young which fall on the age bracket of $20-29$, male, single, permanent in employment status, less than 5 years in service, low monthly net income and they don't have business background. It implies that even though respondents were young, they are already secured in their employment status. Second, the highest personal entrepreneurial capabilities were commitment to work contract, information seeking, opportunity seeking, and systematic planning/ monitoring. The lowest capabilities were risk taking and demand for quality/ efficiency. It implies that respondents were more on information seeking because of their profession while less risk takers since they don't want to lose what they currently have. Third, self-analysis output implies that respondents were capable of being an entrepreneur. Last, the personal entrepreneurial capabilities that need improvement are risk taking, demand for quality/efficiency and self-confidence.
\end{abstract}

\section{Subject Areas}

Behavioral Economics, Entrepreneurship 


\section{Keywords}

Entrepreneur, Teacherpreneur, Teacher Entrepreneur, Entrepreneurial Skills

\section{Introduction}

In the Philippines, teachers tend to find other sources of income due to some financial circumstances. With this, some teachers were entrepreneurs (termed as teacherpreneur) during break time and after office hours. A "teacherpreneur" must know that consumers often choose to shop goods and services online or physically, based on the owner's accessibility, reliability, and customer relationship [1].

Most likely, teachers in the Philippines were connected to direct selling companies. Direct selling is one of the course requirements in a business marketing program that acts as a bridge for learners to the entrepreneurial environment which is the same for teachers [2]. However, there was a lack of cooperation between teachers and subject specialists in teaching entrepreneurship, a lack of entrepreneurship projects in project-based teaching, and a lack of cooperation with school partners, particularly in project-based teaching [3].

From these insights, the researcher would like to assess the personal entrepreneurial capabilities of teacher-entrepreneurs. Also, the researcher would like to evaluate the results of entrepreneurship training of teachers by gauging their gained knowledge through pre and post-test.

\section{Conceptual Framework}

Teacher entrepreneurial preparation is a process that must comprise not only teacher entrepreneurs and their respective organizations, but also a range of key supporters, such as school administrators, their direct supervisors, and the like [4]. In finding opportunities and leveraging innovatively, the teacher still needs to start acting in an entrepreneurial manner [5]. As this prompts an individual to seek endless opportunities, entrepreneurs must learn how to resolve the risk of failure or vulnerability [6].

\section{Objectives of the Study}

This paper determined the profile of the teacher-entrepreneurs and identified the Personal Entrepreneurial Capabilities (PEC) of the aspiring Teacher-Entrepreneurs. Further, this paper assessed the Personal Entrepreneurial Capabilities of the teacher-entrepreneurs as startup for business and evaluated the Personal Entrepreneurial Capabilities of the Respondents before and after the training.

\section{Methodology}

The descriptive method of research was used in this study because it involves 
description, recording, analysis and interpretation of condition that really exists. It is appropriate to use descriptive method in gathering information about the present existing condition [7]. A total of 89 teacher entrepreneur (31 females and 58 males) were surveyed using a questionnaire with likert-scale responses [8].

\section{Results and Discussions}

Table 1 presents the frequency and percentage distribution socio-economic profile of aspiring public school teacher-entrepreneurs. In terms of age, a big number of teacher entrepreneurs were 20 to 29 years old (41.38\%). 58 out of the 89 (65.22\%) teacher entrepreneurs were males and more than half of them $(55.17 \%)$ were still single. As to the employment status, 71 or 79.31 percent were permanently employed and 18 or 20.69 percent were still on a provisional status. But majority of them were only in the service for 5 years or less. They were earning 10,000 pesos and above monthly. However, majority ( $64 \%$ or $72.41 \%$ ) of these public school teachers had already had business background.

Table 1. Profile of the aspiring teacher entrepreneurs.

\begin{tabular}{|c|c|c|c|}
\hline & Profile & f & $\%$ \\
\hline \multicolumn{4}{|l|}{ Age } \\
\hline & 60 and above & 0 & 0.00 \\
\hline & $50-59$ & 9 & 10.34 \\
\hline & $40-49$ & 18 & 20.69 \\
\hline & $30-39$ & 25 & 27.59 \\
\hline & $20-29$ & 37 & 41.38 \\
\hline \multirow[t]{2}{*}{ Sex } & Female & 31 & 34.48 \\
\hline & Male & 58 & 65.52 \\
\hline \multirow[t]{2}{*}{ Civil Status } & Single & 49 & 55.17 \\
\hline & Married & 40 & 44.83 \\
\hline \multicolumn{4}{|c|}{ Employment Status } \\
\hline & Permanent & 71 & 79.31 \\
\hline & Provisional & 18 & 20.69 \\
\hline \multicolumn{4}{|c|}{ Years of Service } \\
\hline & $0-5$ & 74 & 82.76 \\
\hline & $6-10$ & 15 & 17.24 \\
\hline \multicolumn{4}{|c|}{ Monthly Net Income } \\
\hline & Above 10,000 & 64 & 72.41 \\
\hline & 10,000 and below & 25 & 27.59 \\
\hline \multicolumn{4}{|c|}{ Business Background } \\
\hline & Yes & 25 & 27.59 \\
\hline & No & 64 & 72.41 \\
\hline & & $N=8$ & \\
\hline
\end{tabular}


Table 2 showcases the average PEC scores of the respondents according to their entrepreneurial capabilities. On the pre-assessment the highest average score of 19.31 on information setting was posted by the DepEd teachers. This means that the respondents are continuously seeking relevant information regarding business and technical matters. The lowest average of 17.62 on risk taking means majority of the DepEd teachers are still afraid to take risks.

The respondents were doubt to take risk in some sort of situation especially when it involves money while the seeking information was constant. Seeking information is to avoid high risk situations [9].

Table 3 presents the pre-assessment out of 89 teachers, 68 respondents can start with the business plan and have the earmarks to be an entrepreneur, which is equivalent to $76 \%$. In contrary, 21 respondents have the potential but may improve his skills on weak areas, which is equivalent to $24 \%$. Thus, more than $70 \%$ has an earmark of an entrepreneur. The researcher and the DTI Business Counselor conducted the seminar and workshop for the respondents as a tool for entrepreneurial program development. In line with this, post-assessment was given to the respondents.

Potential entrepreneur found out that having a plan is less about accurately predicting the future, and more about setting regular goals, monitor the actual progress toward those goals, and make changes to your business as you learn more about the business situations [10].

Table 4 presents showcases the average PEC scores of the respondents according to their entrepreneurial capabilities. On the pre-assessment the highest average score of 19.31 on information setting was posted by the public school teacher-entrepreneurs. This means that the respondents are continuously seeking relevant information regarding business and technical matters. The lowest average of 17.62 on risk taking means majority of them were still afraid to take risks.

Based on the post-assessment, the same entrepreneurial capability was the

Table 2. Personal Entrepreneurial Capabilities (PEC) of the aspiring teacher entrepreneurs.

\begin{tabular}{lcc}
\hline \multicolumn{1}{c}{ CAPABILITIES } & Mean & RANK \\
\hline Information seeking & 19.31 & 10 \\
Goal setting & 18.86 & 9 \\
Opportunity seeking & 18.82 & 8 \\
Systematic Planning/Monitoring & 18.79 & 7 \\
Persistence & 18.55 & 6 \\
Commitment to work contract & 18.55 & 5 \\
Persuasion and networking & 18.00 & 4 \\
Self confidence & 17.89 & 3 \\
Demand for quality/efficiency & 17.82 & 2 \\
Risk taking & 17.62 & 1 \\
\hline
\end{tabular}


Table 3. Self-assessment of the aspiring teacher-entrepreneurs.

\begin{tabular}{cccl}
\hline Scores & f & $\%$ & \multicolumn{1}{c}{ Description } \\
\hline between 60 and 75 & 68 & 76.00 & $\begin{array}{l}\text { you can start your business plan and you } \\
\text { have the earmarks of an entrepreneur } \\
\text { you have potential but need to push } \\
\text { yourself and you may improve your skills } \\
\text { in your weak areas or you can someone } \\
\text { with the skills }\end{array}$ \\
\hline
\end{tabular}

Table 4. Personal entrepreneurial capabilities of the respondents before and after the training.

\begin{tabular}{lccccc}
\hline \multirow{2}{*}{ Scores } & \multicolumn{2}{c}{ Pre-test } & \multicolumn{2}{c}{ Post-test } & \multirow{2}{*}{$\begin{array}{c}\text { Difference } \\
\text { (Post-test-Pre-test) }\end{array}$} \\
\cline { 2 - 5 } & Mean & RANK & Mean & RANK & 0.17 \\
Information seeking & 19.31 & 10 & 19.48 & 10 & 0.17 \\
Goal setting & 18.86 & 9 & 19.03 & 9 & 0.15 \\
Opportunity seeking & 18.82 & 8 & 18.97 & 8 & 0.07 \\
Systematic planning and & 18.79 & 7 & 18.86 & 7 & 0.03 \\
monitoring & 18.55 & 6 & 18.58 & 5 & 0.07 \\
Persistence & 18.55 & 5 & 18.62 & 6 & 0.14 \\
Commitment to work contract & 18.00 & 4 & 18.14 & 2 & 0.21 \\
Persuasion and networking & 17.89 & 3 & 18.10 & 1 & 0.42 \\
Self confidence & 17.82 & 2 & 18.24 & 3 & 0.83 \\
Demand for quality/efficiency & 17.62 & 1 & 18.45 & 4 & \\
Risk taking & & & & & \\
\hline
\end{tabular}

highest average PEC score which was information seeking and increases its level of 0.17 . Goal setting from 18.86 to 19.02 , an increase of 0.17 ; opportunity seeking from 18.82 to 18.97 , an increase of 0.15 ; systematic planning and monitoring from 18.79 to 18.86 , an increase of 0.07 ; persistence from 18.55 to 18.58 , an increase of 0.03 ; commitment to work contract from 18.55 to 18.62 , an increase of 0.07 ; persuasion and networking from 18 to 18.14 , an increase of 0.14 ; self-confidence from 17.89 to 18.1 , an increase of 0.21 ; demand for quality and efficiency from 17.82 to 18.24, an increase of 0.42 and; risk taking from 17.62 to 18.45 , an increase of 0.83 . Thus, all capabilities increase its level which means the average personal capabilities improved. There was no significant difference of the level of entrepreneurial capabilities and socio-economic profile based on PEC.

The training and development of entrepreneurs gained an amount of significance in the recent past, for it is purported to contribute to the socio-economic development of a country. The training helped the individual develop entrepreneurial qualities that contributed to industrial growth of a country.

\section{Conclusions and Recommendations}

The researcher pointed out the following significant conclusions: first, 
majority of the respondents were young, which fall on the age bracket of 20 29 , male, single, permanent in employment status, less than 5 years in service, low monthly net income and they don't have business background. It implies that even though respondents were young, they are already secured in their employment status. Second, the highest personal entrepreneurial capabilities were commitment to work contract, information seeking, opportunity seeking, and systematic planning/monitoring. The lowest capabilities were risk taking and demand for quality/efficiency. It implies that respondents were more on information seeking because of their profession while less risk takers since they don't want to lose what they currently have. Third, self-analysis output implies that respondents were capable of being an entrepreneur. Last, the personal entrepreneurial capabilities that need improvement are risk taking, demand for quality/efficiency and self-confidence.

To develop the entrepreneurial capabilities of an individual is to undergo a program that is helpful to strengthen the entrepreneurial motive and acquire skills needed as an entrepreneur. The researcher recommends the following: As a young adult, it would be preferable to gain business experience. It feeds your experience and takes you one level higher to your exposure. An individual who has the lowest level on entrepreneurial capabilities must attend the seminar and workshop to be more equipped about business opportunities. Self-check is important to determine your capabilities in entrepreneurship. To improve the risk taking and demand for quality/efficiency merely undergoes an entrepreneurial program development. From attending seminar and workshop that will equip the knowledge about entrepreneurship into putting up a business that will develop more of your entrepreneurial capabilities, all individuals have their own capabilities in doing such thing regardless of socio-economic profile as long there is a will.

\section{Conflicts of Interest}

The author declares no conflicts of interest regarding the publication of this paper.

\section{References}

[1] Santos, K.E.S. (2020) Online Marketing: Benefits and Difficulties to Online Business Sellers. International Journal of Advanced Engineering Research and Science, 7, 159-163. https://doi.org/10.22161/ijaers.73.27

[2] Santos, K.E.S. (2020) Developed Skills of Marketing Students through Direct Selling in Nueva Ecija. Open Access Library Journal, 7, 1-5. https://doi.org/10.4236/oalib.1106111

[3] Aniroh, K. (2018) Cultural Traits in Language Teaching: A Review of English Language Teachers and Entrepreneurs. TESOL International Journal, 13, 9-25.

[4] Berry, B., Byrd, A. and Wieder, A. (2013) Teacherpreneurs: Innovative Teachers Who Lead But Don't Leave. John Wiley \& Sons, Hoboken.

[5] Heinonen, J. and Poikkijoki, S.A. (2006) An Entrepreneurial-Directed Approach to 
Entrepreneurship Education: Mission Impossible? Journal of Management Development.

[6] Gautam, M.K., Singh, D. and Kumar, S. (2015) Entrepreneurship Education: Concept, Characteristics and Implications for Teacher Education.

[7] Creswell, J.W. (2014) A Concise Introduction to Mixed Methods Research. Sage Publications, Thousand Oaks.

[8] Vagias, W.M. (2006) Likert-Type Scale Response Anchors. Clemson International Institute for Tourism \& Research Development, Department of Parks, Recreation and Tourism Management, Clemson University, Clemson, SC.

[9] Choo, C. (2017) Seeking and Avoiding Information in a Risky World. Information Research, 22, 1-27.

[10] Parsons, M. (2019) Do You Need a Business Plan? Scientific Research Says Yes. BPlans Start a Business Made Easy.

https://articles.bplans.com/do-you-need-a-business-plan-scientific-research-says-ye $\underline{\mathrm{s} /}$ 